$$
\begin{aligned}
& \text { بروسى هيستولوزيكى اثرات نانو دىاكسيد تيتانيوم بر دوى رشل و نمو جوانة اولين دنفان آسياب } \\
& \text { in vivo دنين موش نث اد }
\end{aligned}
$$

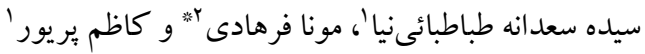

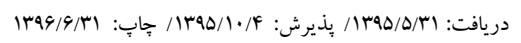

$$
\begin{aligned}
& \text { اخرُوه زيستشناسى، واحد علوم و تحقيقات تهران، دانشگاه آزاد اسلامى، تهران، ايران }
\end{aligned}
$$

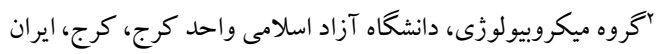

$$
\begin{aligned}
& \text { mona.farhadi@kiau.ac.ir :مسئول مكاتبات }
\end{aligned}
$$

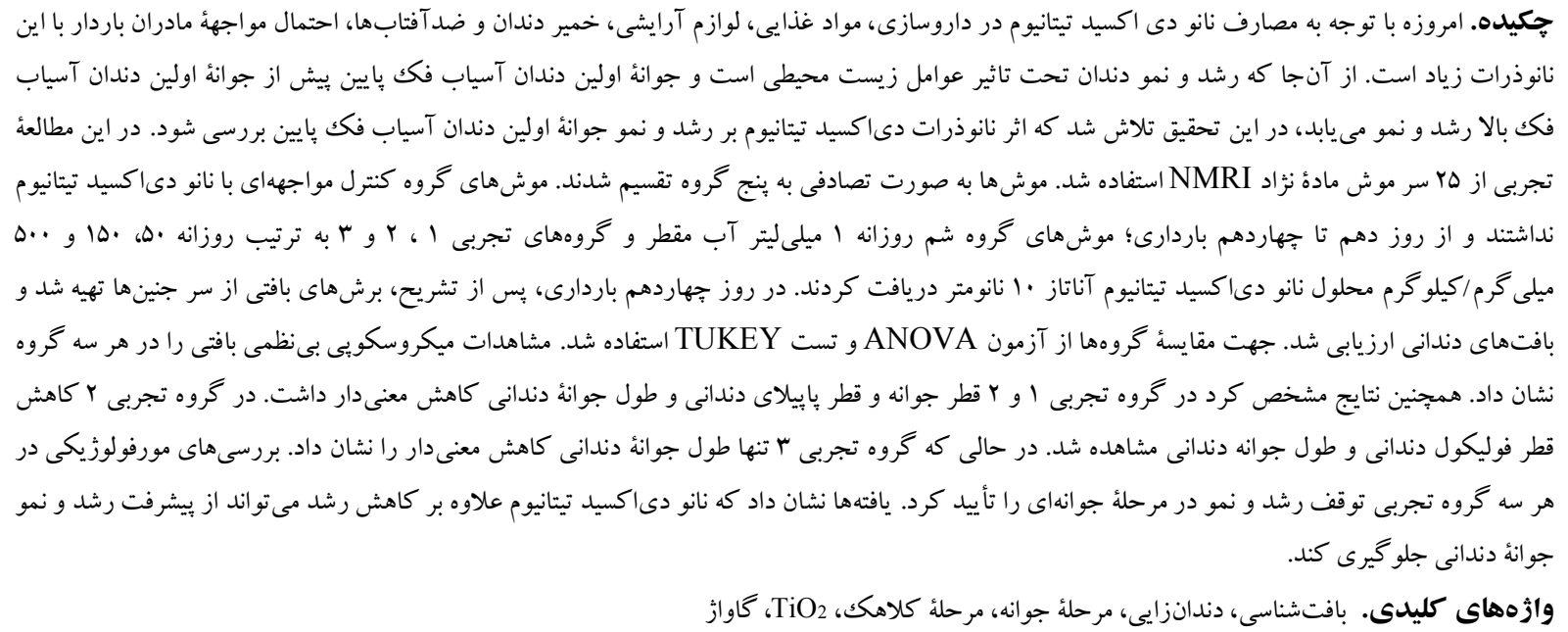

\title{
Histological investigation of the effects of nano titanium dioxide on the development of the first mandibular molar bud in NMRI mouse strain in vivo
} Seyedeh Sadaneh Tabatabaei Nia ${ }^{1}$, Mona Farhadi ${ }^{2 *} \&$ Kazem Parivar ${ }^{1}$ Received 21.08.2016/ Accepted 24.12.2016/ Published 22.09.2017

\begin{abstract}
${ }^{1}$ Department of Biology, Tehran Science and Research Branch, Islamic Azad University, Tehran, Iran ${ }^{2}$ Department of Microbiology, Islamic Azad University of Karaj, Islamic Azad University, Karaj, Iran *Correspondent author: mona.farhadi@kiau.ac.ir
\end{abstract}

\begin{abstract}
Nowadays, with the applications of titanium dioxide nanoparticles $\left(\mathrm{TiO}_{2}-\mathrm{NPs}\right)$ in pharmacy, food industry, cosmetics, toothpaste and sunscreens, pregnant women are exposed to nanoparticles. Since tooth development is vulnerable to environmental impacts and mandibular first molar bud develops before maxillary first molar bud, in this experimental study the effects of $\mathrm{TiO}_{2}$-NPs on the development of first mandibular molar bud in NMRI mouse was investigated. Twenty five female NMRI mice were randomly divided into five groups $(\mathrm{N}=5)$; Control group (pregnant mice without any treatment), sham group (treated with distilled water), experimental groups 1, 2 and 3 (treated with 50,150 and $500 \mathrm{mg} / \mathrm{kg} \mathrm{BW} \mathrm{TiO}_{2}-\mathrm{NPs}$, respectively, via gavage from embryonic days 10.5-14.5). On E14.5, embryos heads were prepared for histological examination and dental tissues were evaluated. Data were analyzed by ANOVA and post hoc test (Tukey). Microscopic observation showed tissue disorganization in experimental groups. Findings showed that in experimental groups 1 and 2, the diameter of bud and dental papilla and the length of dental bud decreased significantly. In experimental group 2, decrease in the diameter of dental follicle, dental bud and dental papilla and the length of dental bud was significant. On the other hand, in experimental group 3, only the decrease in the length of dental bud was significant. These findings showed that nano titanium dioxide can reduce the size of dental buds and is capable of preventing tooth development.
\end{abstract}

Keywords. histology, odontogenesis, bud stag, cap stage, $\mathrm{TiO}_{2}$, gavage 
ويشين مغز (Umezawa et al., 2012)، ايجاد تغييرات عصبى-

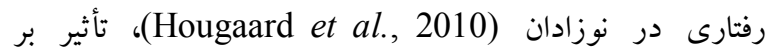
(Dehghani et al., اسبرماتوزنز، كاهش اسبرماتيد و سلولهاى 2014; Guo et al., 2009) التهاب تخمدان و آترزى فوليكولها (Zhao et al., 2013)، (Duan et al., 2010; Jeon et al., 2012; آسيب كبدى Wang et al., 2007)

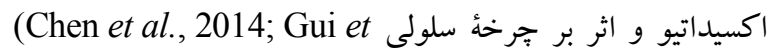

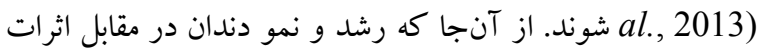
زيست محيطى آسيبذيز است، در اين تحقيق اثر اين نانو ذره را

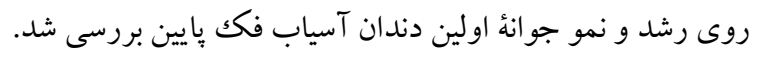

\section{مواد و روشها}

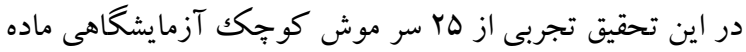

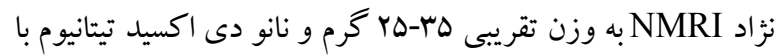
قطر ·ل انانومتر تهيه شده از شركت نانو يارس ليما، استفاده شد.

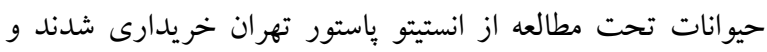

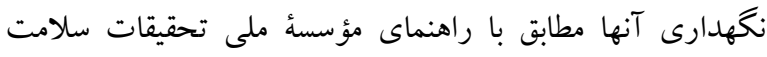

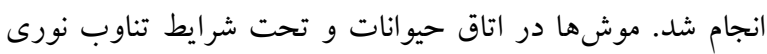

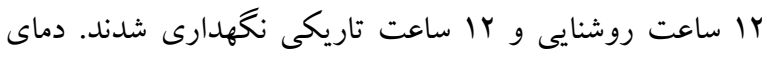

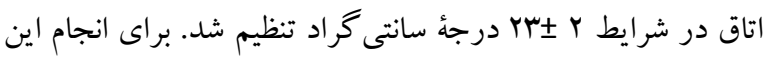

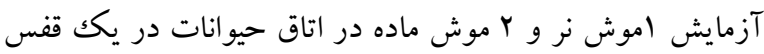

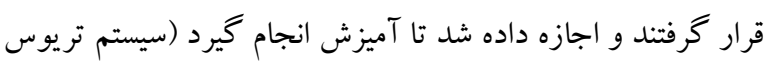

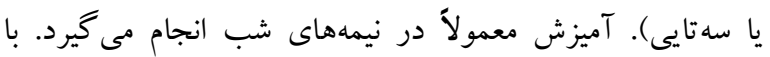

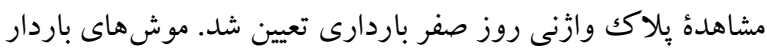
در گروههاى: كنترل، شم و تجربى (غلظتهاى مختلف نانو) مورد

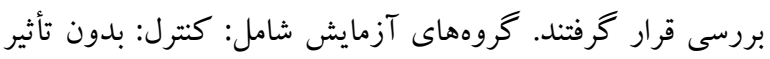

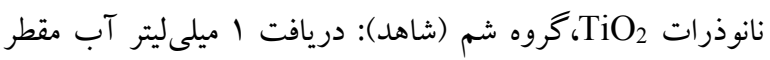
به عنوان حلال نانوذرات؛ گروه تجربى ا: دريافت 1 ميلىليتر

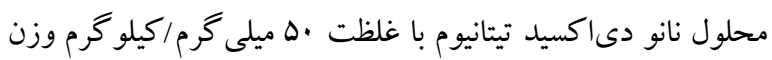
بدن؛ گروه تجربى r: دريافت ا ميلىليتر محلول نانو دى داكسيد

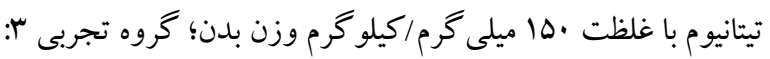

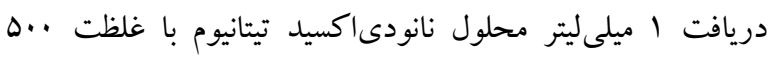

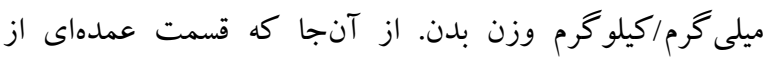

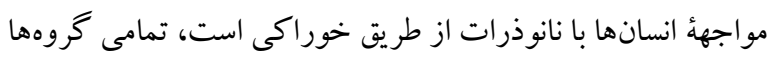

مقدمه نانوتكنولوزى يا فناورى نانو يكك دانش بين رشتهاى گسترده

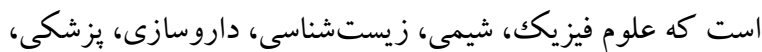
مهندسى و غيره را در برمى گيرد. اين دانش توانايى دست كارى

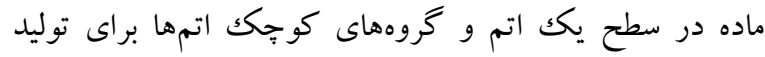

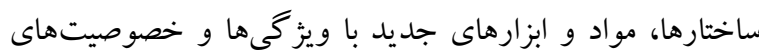
(Iavicoli et al., منحصر به فرد فيزيكى و شيميايى را دارد (2011. اين مواد ممكن است از طريق يوست، تنفس و به صورت

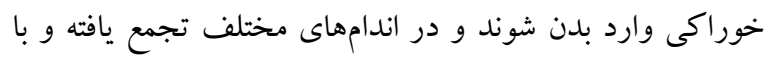

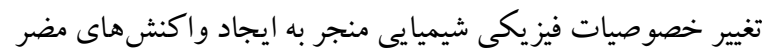

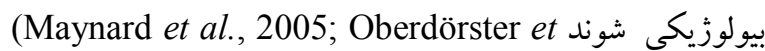
al., 2005) برخى از نانوذرات، بسته به تركيب و اندازه آنها،

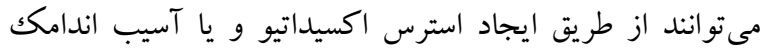

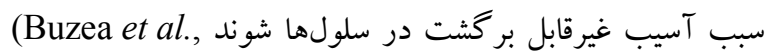
(2007. يودر دىاكسيد تيتانيوم انحلال يذيرى كمى دارد و به طور

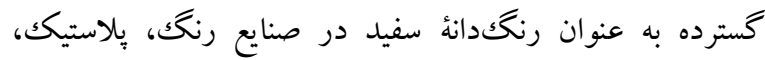

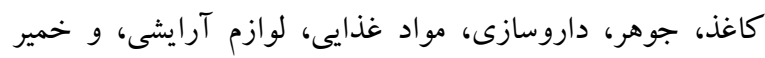

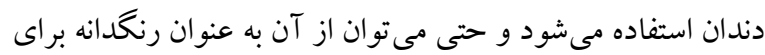
سفيدكردن شير بلدون خربى استفاده كرد. اين نانوذرات همجئين

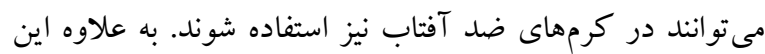

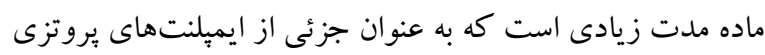

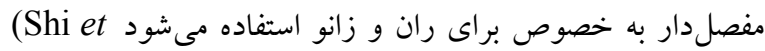

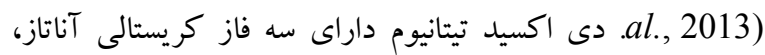

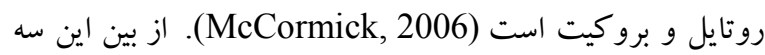
فاز روتايل بايدارتر است و دو فاز ديخر در اثر حرارت به به روتايل تبديل مىشوند (Xiao et al., 2009). مشخص شده است كه فاز آناتاز .. برابر سميت سلولى بيشترى نسبت به فاز روتايل ايجاد

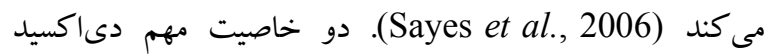
تيتانيوم، خاصيت فتو كاتاليستى و فوق آب دوستى آن است. از اين

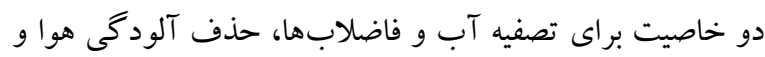
ساختمانها، تسريع واكنشهاى فتوشيميايى مانند توليد هيدروزن، ساخت سطوح و لايههاى ضد مه و شيشهاى خود تميزشونده

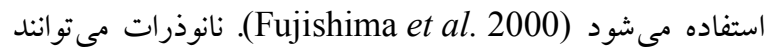
سبب نكروزه شدن بافتها (Hayati Roodbari et al., 2014)، اختلال در زنهاى مرتبط با سيستم نورونهاى دويامين و قشر برو 
طول و عرض سر جنينها در گروههاى تجربى نسبت به گروه

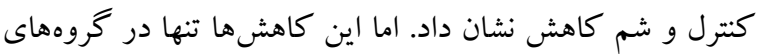

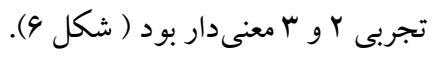

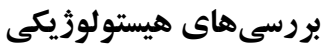
بررسى اندام مينا نشان دهندة كاهش معنىدار قطر اندام مينا در كروههاى تجربى ا و Y و همجينين كاهش معنى دار طول اندام مينا در همة گروههاى تجربى نسبت به گروه كنترل شده است (شكل V V V V برسى قطر فوليكول دندانى نشان داد كه نانو دى اكسيد

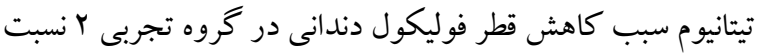

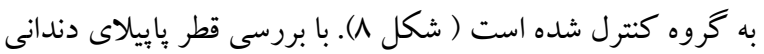
مشخص شد كه گروههاى تجربى ا و r نسبت به گروه كنترل و

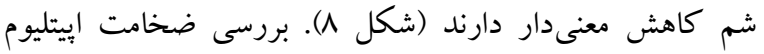
مينايى داخلى (IEE) و ضخامت إيتليوم مينايى خارجى (OEE)

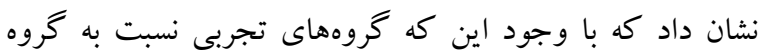
كنترل و شم كاهش اندكى داشتند، اما اين كاهش معنىدار نيست.

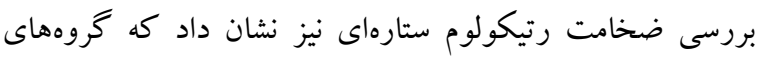
تجربى اختلاف معنى دارى با گروه كنترل و شم ندارند. بررسى مراحل مورفولوزيكى جوانه اولين دندان آسياب فكى هإيين بررسىها نشان داد كه درصد تعداد جوانههاى دندانى مرحلة كلاهك در گروههاى تجربى كاهش يافته است. در گروه كنترل

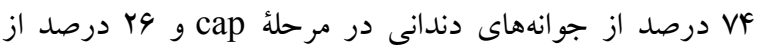

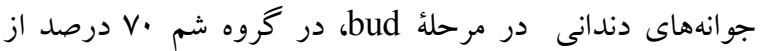

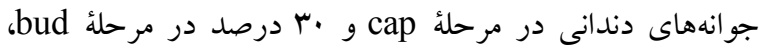
كروه تجربى 1! ·4 درصد از جوانههاى دندانى در مرحلة cap و

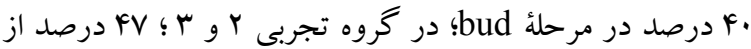
جوانههاى دندانى در مرحلة cap و بها درصد در مرحلة bud قرار داشتند. بررسى اين دادها نشان مىدهد كه كاهش تعداد جوانههاى دندانى مرحلة cap و افزايش تعداد جوانههاى دندانى مر حلة bud همؤ كروههاى تجربى معنى دار است (شكل 9).

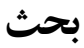
با افزايش استفاده از نانو دىاكسيد تيتانيوم در زندكى روزمره

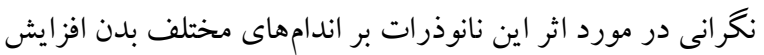

يكك بار در روز به صورت روزانه؛ از روز دهم تا جهاردهم باردارى

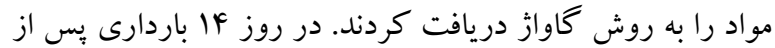

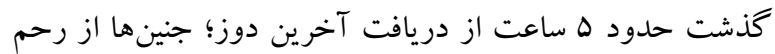
خارج و سر آنها جدا شد و به مدت V-N ساعت در محلول

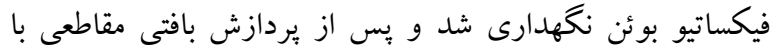

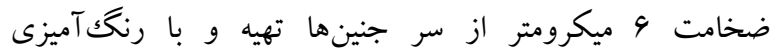
هماتو كسيلين ائوزين رنغكآميزى شد. لامهاى آماده شده تحت مطالعات ميكروسكويى و ماكروسكويى قرار گر فتند و متغير هايى از قبيل طول و عرض سر جنينها، قطر فوليكول دندانى، قطر جوانه دندانى، طول جوانه دندانى، قطر پإييلاى دندانى، ضخامت إيتليوم

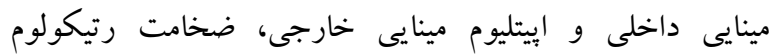
ستارهاى و بررسى مراحل مورفولوزيكى جوانهائ اولين دندان آسياب فكك بايين تحت مطالعه قرار گرفت. دادههاى خام با استفاده

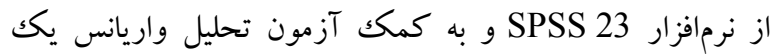
طرفه ANOVA و سبس آزمون TUKEY مورد بررسىهاى آمارى قرار گرفتند. جهت بررسى نتايج، 0.05>0.

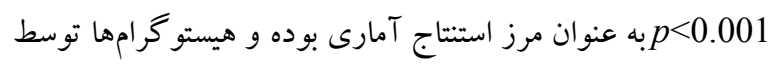

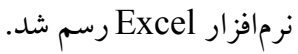

\section{تتايج} در فتوميكروگراف جوانه دندانى گروه كنترل (شكل A-A (1) و

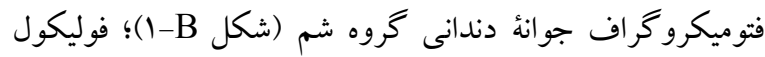

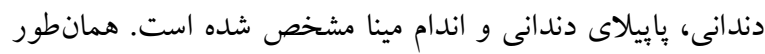
كه در تصاوير مشاهده مىشود، با افزايش دوز نانودىاكسيد

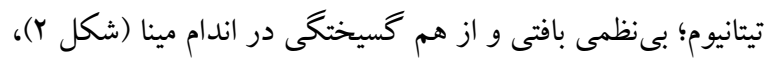
اختلال در زمانبندى رشد و نمو دندان (شكل ؟r)، كاهش اندازه

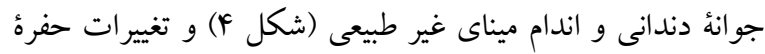

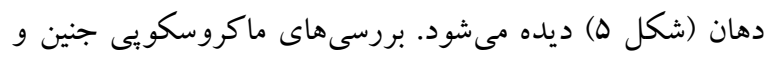

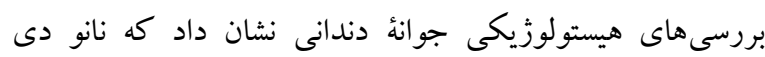

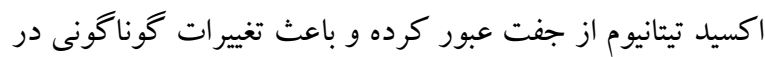

$$
\text { جو انهاى دندانى مى شود. }
$$

بروسى هاى ماكروسكويى جنين

در بررسىهاى ماكروسكويى طول سر (رأس جمجمه تا زير يوزه) و عرض سر (فاصلهُ بين دو گُش) مورد مطالعه قرار گرفت. 

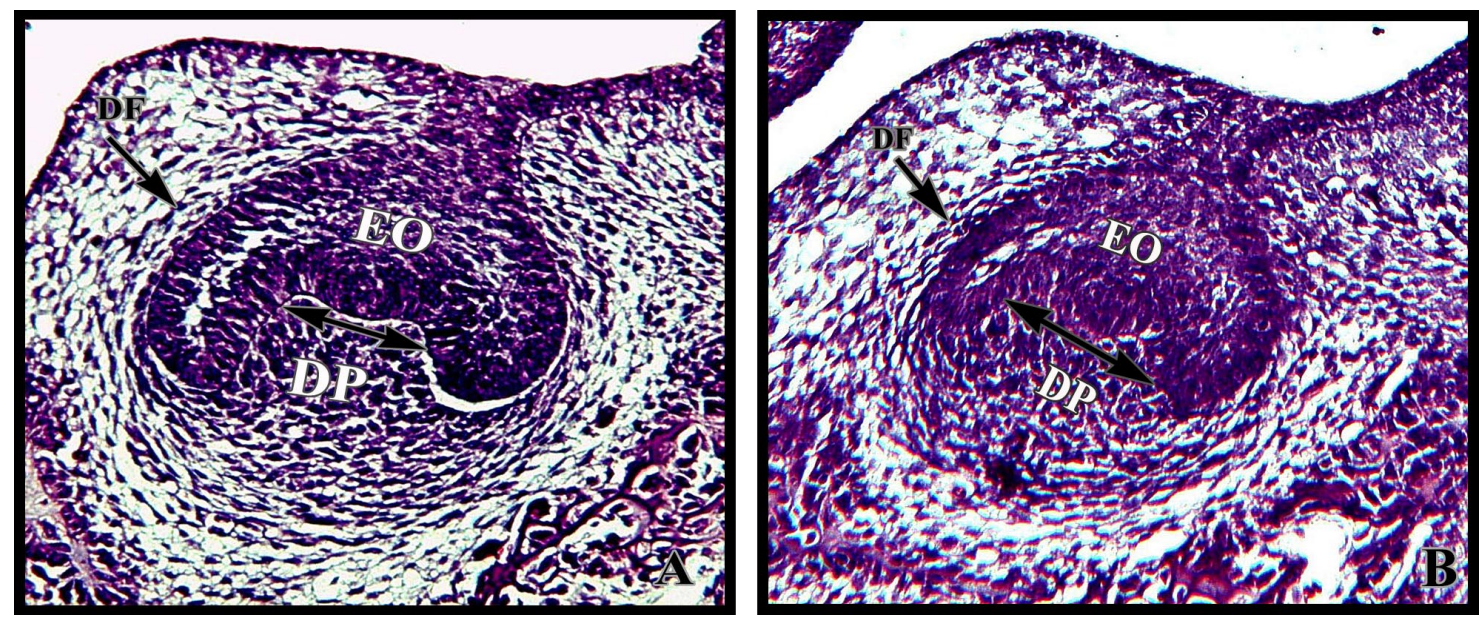

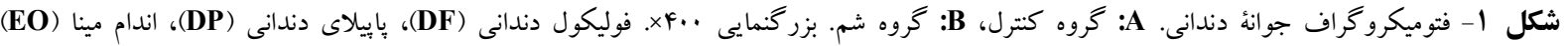

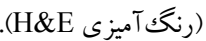

Fig. 1. Dental bud photomicrograph. A: control, B: sham. Magnification $\times 400$. Dental follicle $($ DF $)$, enamel organ $($ EO), dental papilla (DP) (H\&E staining).
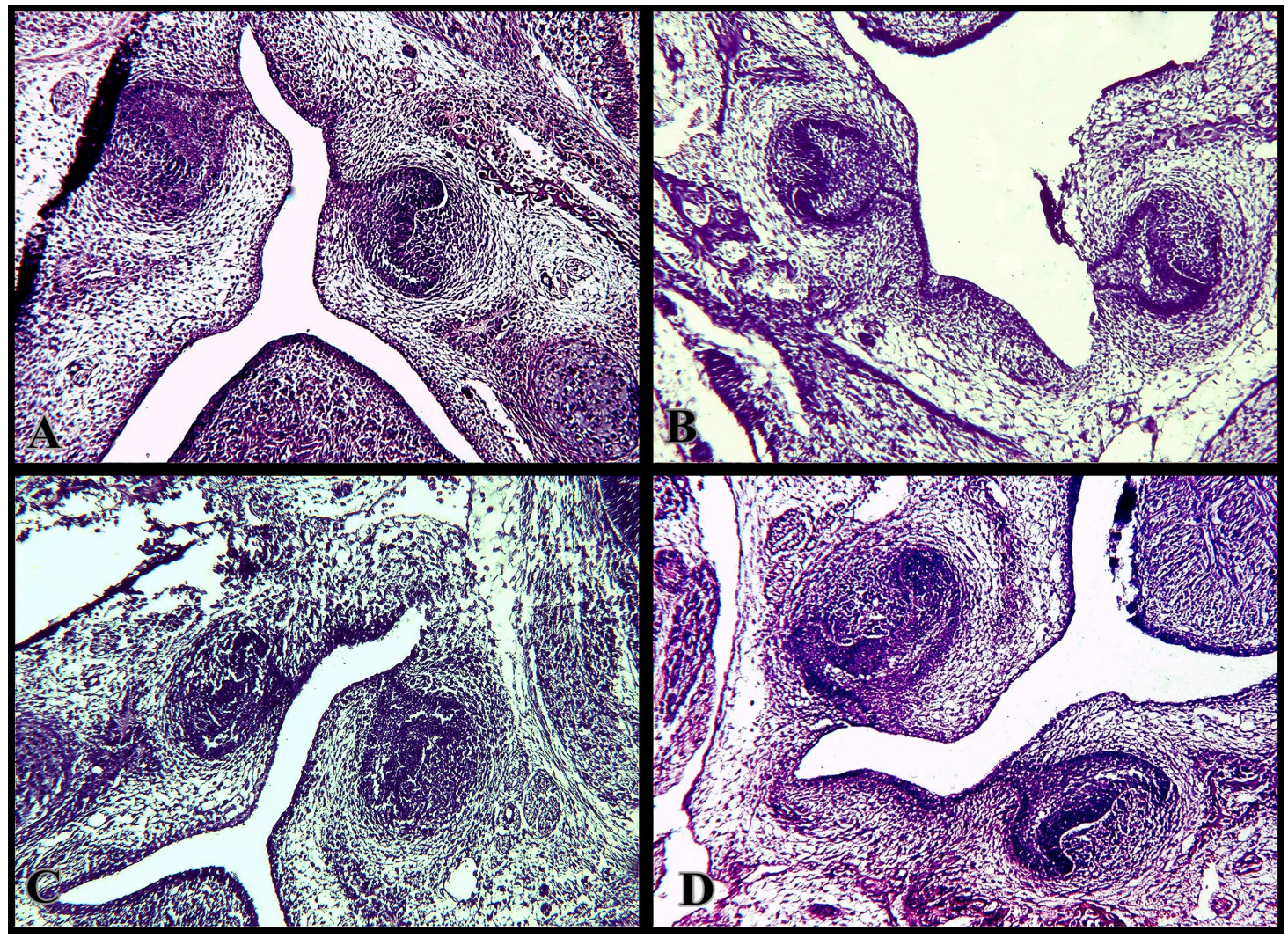

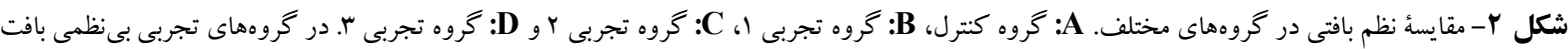

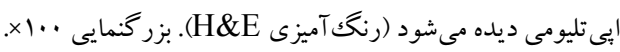

Fig. 2. Comparison of tissue disruption in different groups. A: control group, B: experimental 1, C: experimental 2, D: experimental 3. Epithelial tissue disruption showed in all experimental groups. Magnification 100× (H\&E staining). 


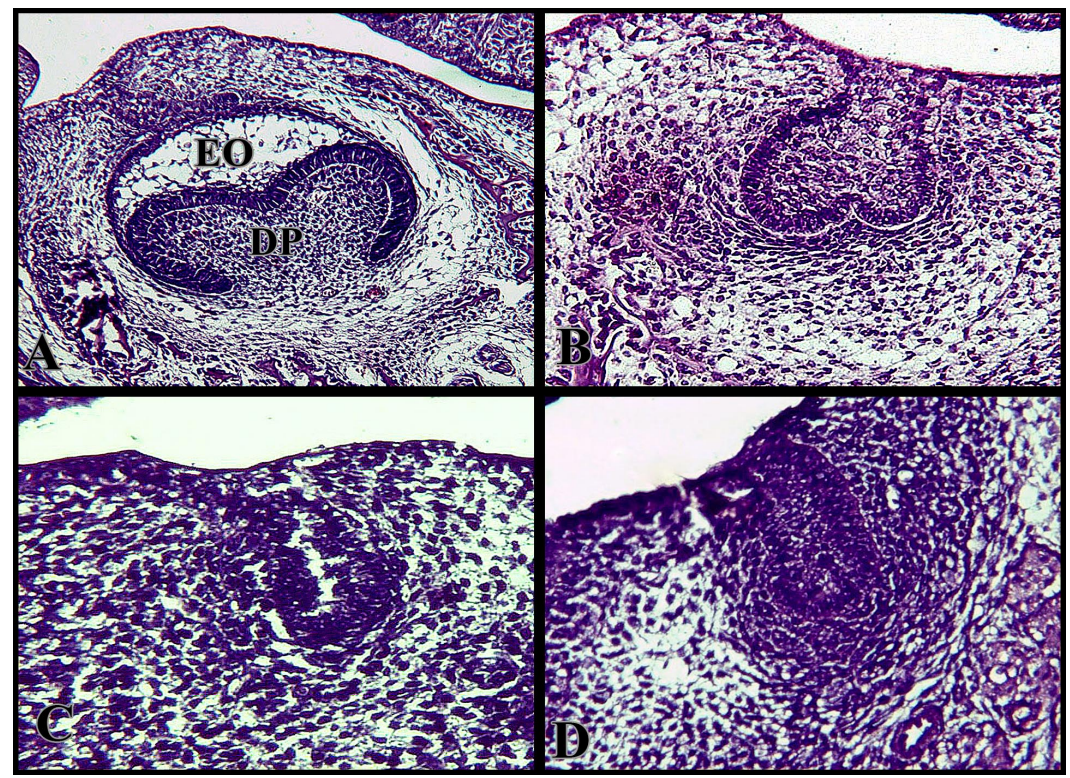

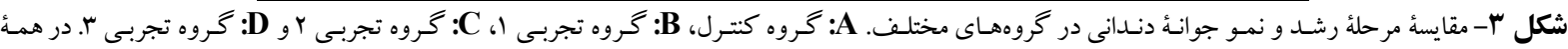

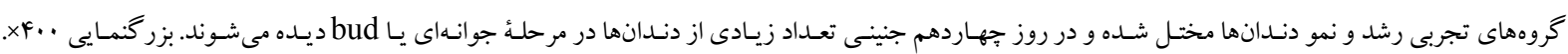

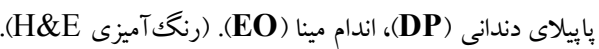

Fig. 3. Comparison of tooth bud development in different groups. A: Control, B: Experimental 1 (50 mg/kg BW Tio2NPs), C: Experimental 2 (150 mg/kg BW Tio2-NPs), D: Experimental 3 (500 mg/kg BW Tio2-NPs). In all experimental groups tooth development was impaired and in E14 a large number of teeth were in the bud stage. Magnification $\times 400$. Enamel Organ (EO), Dental Papilla (DP). (H\&E staining).

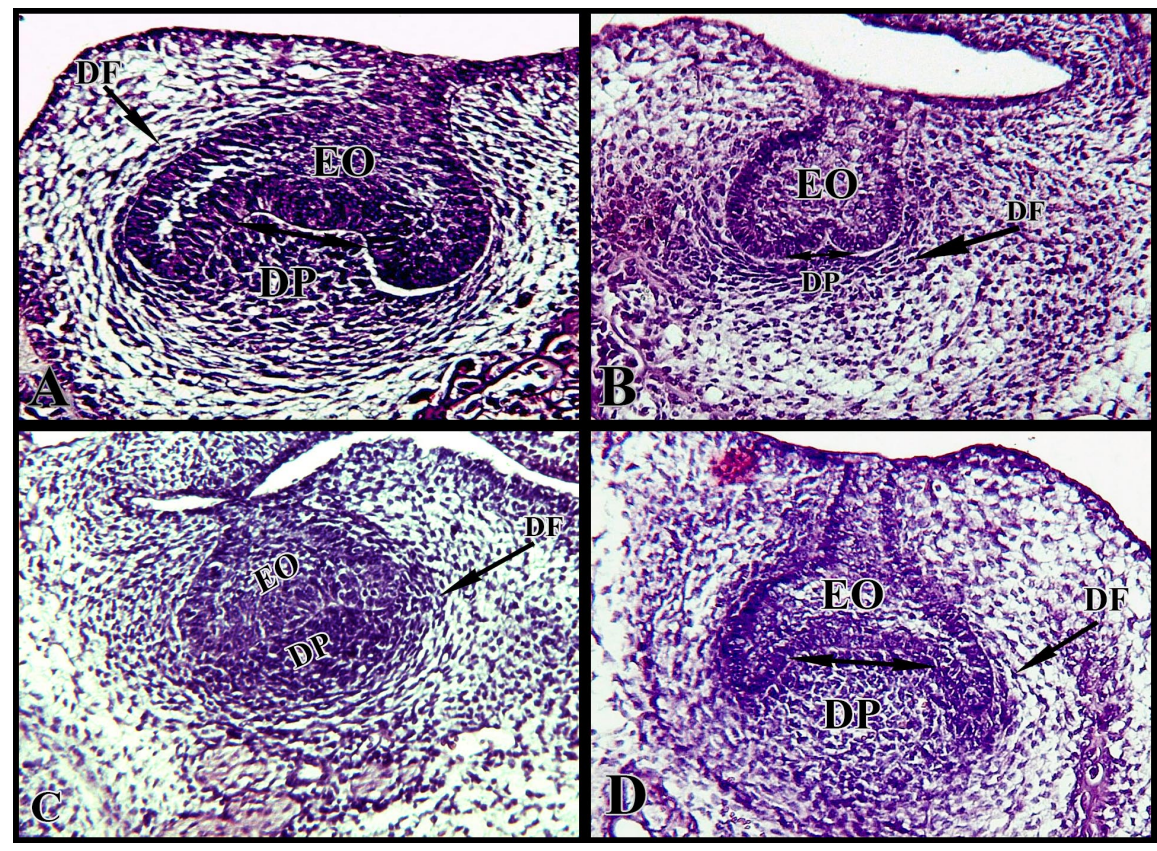

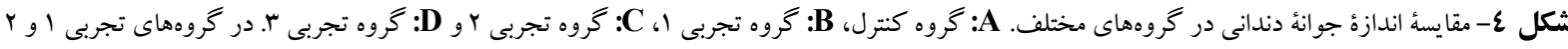

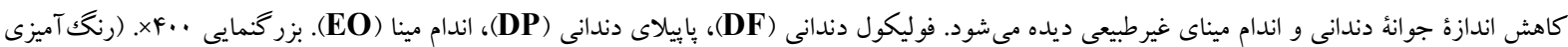

. $(\mathrm{H} \& \mathrm{E}$

Fig. 4. Comparison of tooth bud size in different groups. A: Control, B: experimental 1, C: experimental 2 and D: experimental 3. In the experimental groups 1 and 2 reduction in tooth bud size and abnormal enamel organ was observed. Magnification $\times 400$. Dental follicle (DF), enamel organ (EO), dental papilla (DP). (H\&E staining). 


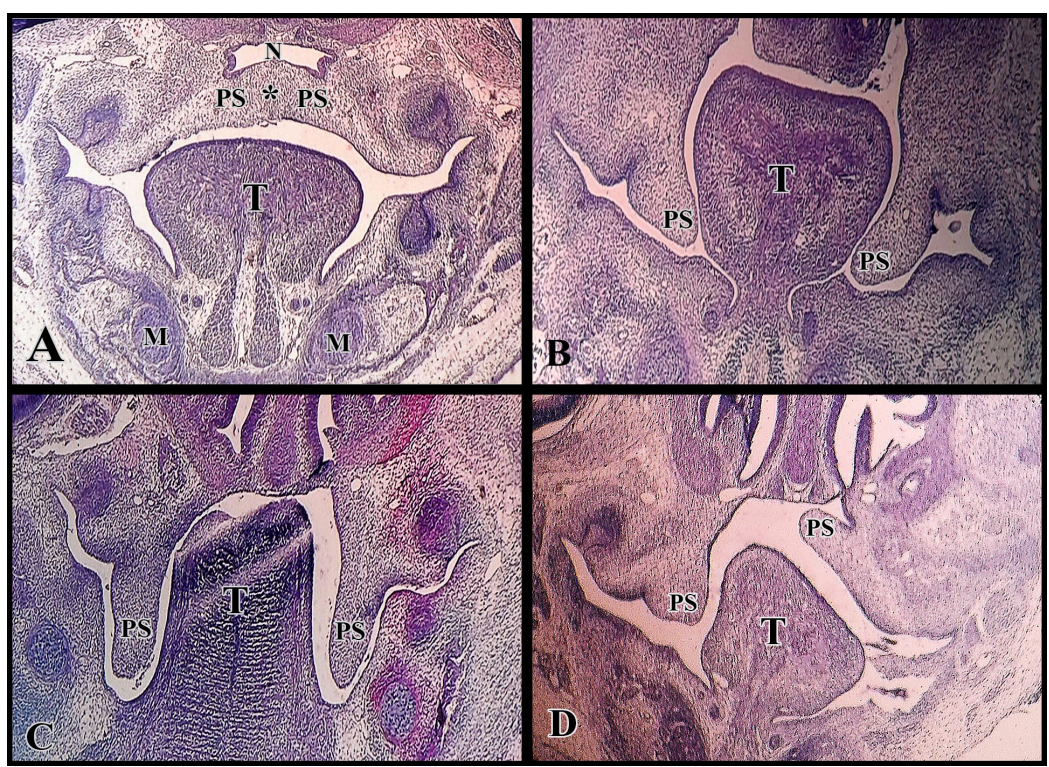

شكل 0- مقايسٔ شكل حفرة دهان و كام در گروه A: كنترل با B, C, D: گروه تجربى r. در گروه تجربى Y حفرة دهان غيرطبيعى شده و شكاف كام نيز ديده

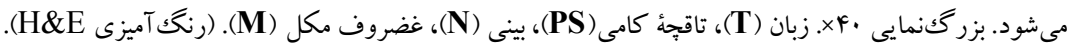

Fig. 5. Comparison of the shape of the oral cavity and the palate in A: control group with B, C, D: experimental group 2. In the experimental group 2 , oral cavity became abnormal and cleft palate was observed. Magnification $\times 40$. Tongue (T), palate shelf (PS), nose (N), Meckel's cartilage (M). (H\&E staining).

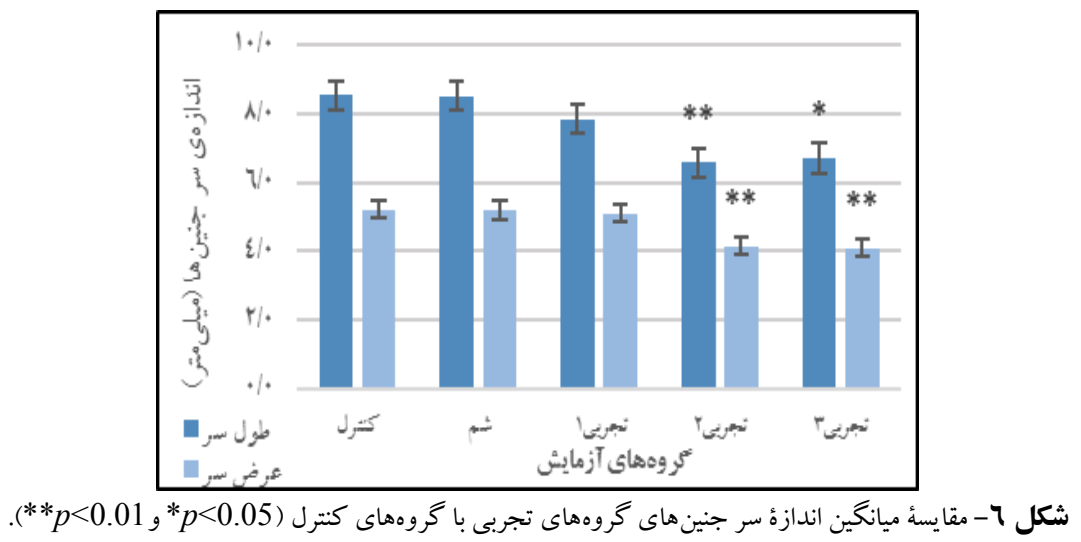

Fig. 6. Comparison of the mean size of embryos' heads of experimental groups with the control group $(* p<0.05$, $*^{*} p<0.01$ ).

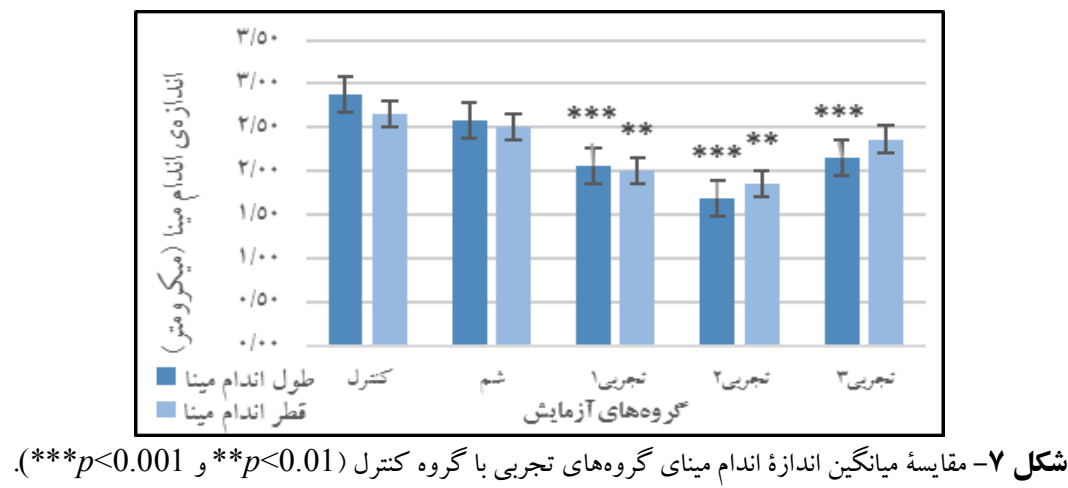

Fig. 7. Comparison of the mean size of enamel organ between experimental groups with control group (** $p<0.01$, $* * * p<0.001)$. 


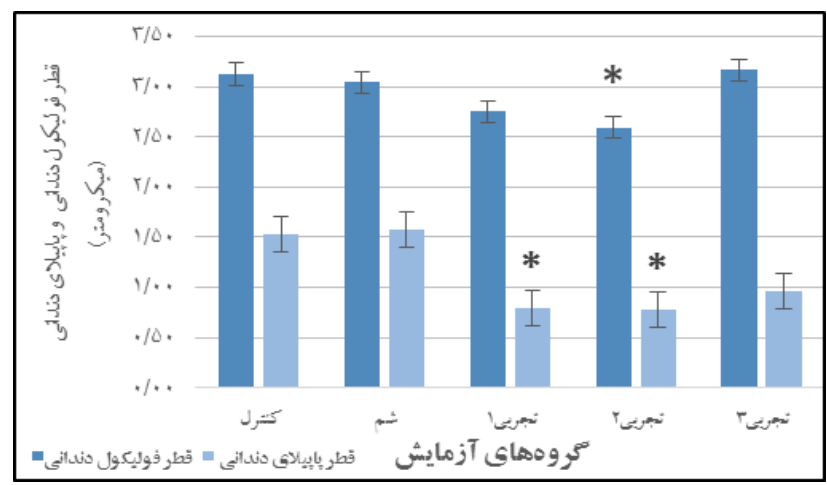

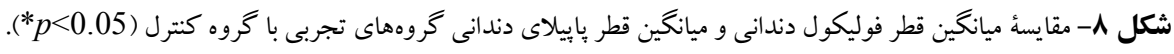

Fig. 8. Comparison of the mean diameter of the dental follicle and the mean of the dental papilla in experimental groups with those in the control group $\left({ }^{*} p<0.05\right)$.

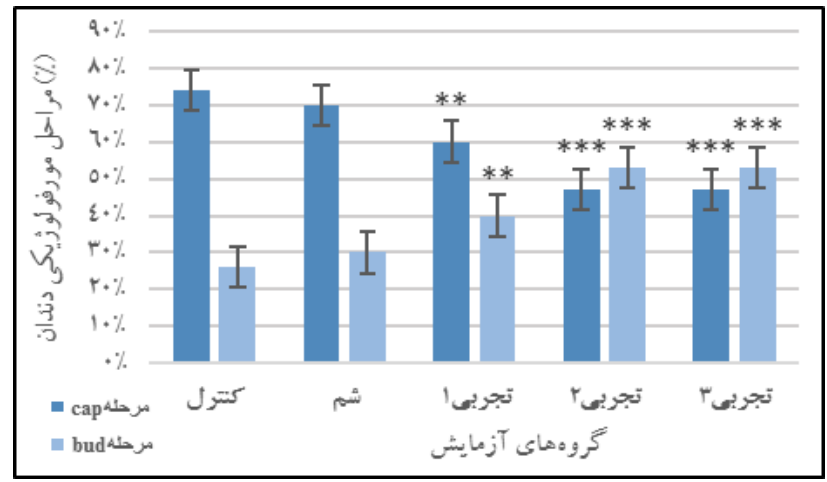

شكل q- مقايسٔ مراحل مورفولوزيكى مختلف گروههاى تجربى با گروه كنترل و شم (

Fig. 9. Comparison of the morphological stages of experimental groups with the control and sham groups $(* * p<0.01$, $* * * p<0.001)$.

مراحل رشد و نمو دندان موش NMRI در تحقيق حاضر و مقايسٔ نتايج با مطالعاتى كه در كذشته روى مراحل رشد و نمو دندان گونه هاى ديخر جوندگان صورت گرفته است، مشخص شد كه زمانبندى رشد و نمو دندان بسيار وابسته به نوع گونه جانور است. (2006) با مطالعهُ موشهاى نزاد Niukkonen كرد كه آغاز دندانزايى در حدود روزهاى ||-1.1 بوده و روز جهاردهم جوانهاى دندانى در مرحله كلاهكى هستند. نتايج تحقيق حاضر روى مرحلهُ رشد و نمو جوانه اولين دندان آسياب فك يايين؛ همانند نتايج Kiukkonen روى موش نزاد NMRI بود. Gaete و همكاران (2004) زمانبندى رشد و نمو جوانه دندانى موش سوية ICR/Jcl را بررسى كردند و مطرح كردند كه اولين تغييرات مورفولوزيكى مربوط به بيدايش جوانههاى دندانى در روز E12.5 ديده مى شود و همجينين مطرح نمودند كه در روز

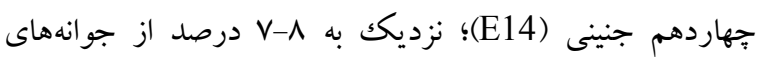

يافته است. در كذشته اثر احتمالى نانوذرات دىاكسيد تيتانيوم بر

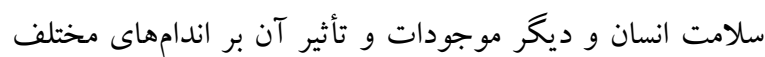
تحت بررسى گرفته است.

مطالعات مختلف روى موش هاى باردار ثابت كرده كه نانوذرات دىاكسيد تيتانيوم آثار مختلفى روى جنينها و نوزادان آنها دارد و اين نتايج نشاندهنده اين است كه اين نانوذرات قادر به عبور از جفت هستند (Hougaard et al., 2010). در تحقيق حاضر نيز كاهش طول و عرض سر جنينها، عبور اين مواد را تأييد كرد. طول سر جنينها در گروه تجربى ا و گروه تجربى جنينها نيز در گروههاى تجربى ب و r كاهش نشان داد. در گذشته مطالعات زيادى روى زمانبندى و مرحلهبندى رشد و نمو دندان گونههاى مختلف جوندگان صورت گرفته است (Cohn, 1957; Dechici \& Moura, 2005; Hiatt et al., 1974; Kiukkonen, 2006; Lefkowitz et al., 1953; Payne et al., 1977; Russo \& Gartner, 1987) 
(Heikkinen et al., شيرى و دائمى كودكى را كاهش دهد

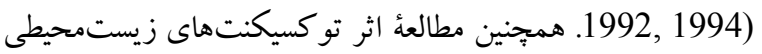

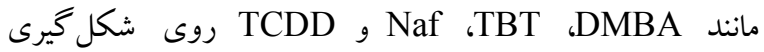
بافتهاى سخت دندان نشان داد كه اين مواد مىتواند آثار مختلفى از جمله كاهش وابسته به غلظت در اندازه دندان، دفرمه دانه

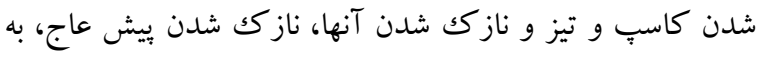
تعويق انداختن معدنى شدن عاج، كاهش ميناى دندان و حتى عدم

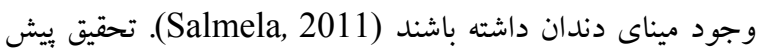

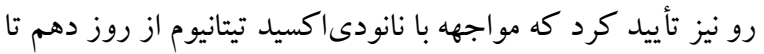
جهاردهم جنينى؛ يعنى از مرحلة آغاز رشد و نمو دندان تا مرحلة كلاهك، مى تواند سبب كاهش قطر فوليكول دندانى، قطر اندام مينا، طول اندام مينا و قطر بايِيلاى دندانى شود. قطر فوليكول

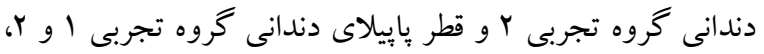

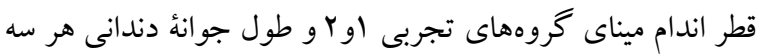
كروه تجربى كاهش بيدا كرد. در مطالعهاى مطرح شد كه آيويتوز

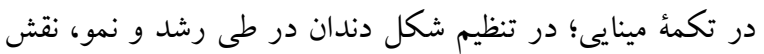

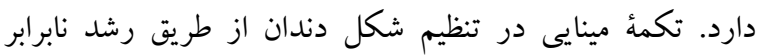

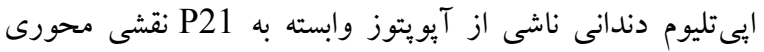

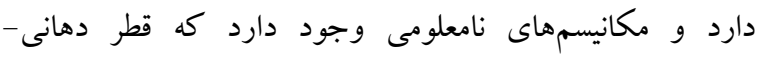

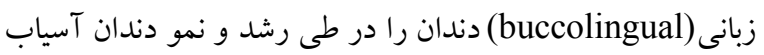

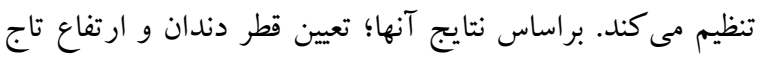
در رشد و نمو دندان آسياب توسط آيو يتوز سلولى كره ميناى اوليه كنترل مىشود. تصور مىشود كه ناهنجارىهاى دندانى مانند

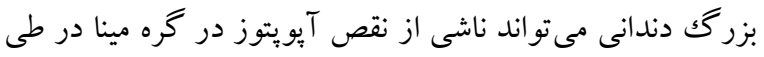

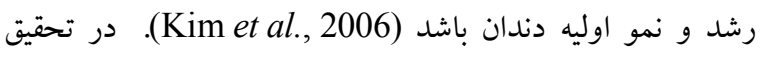

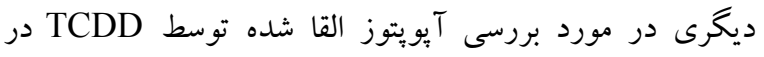

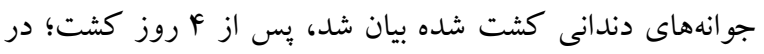
جوانهاى دندان آسياب اول و دوم يكك توده سلولهاى آيو -

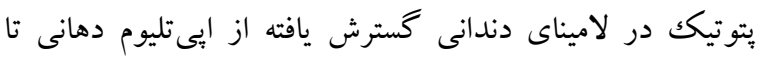

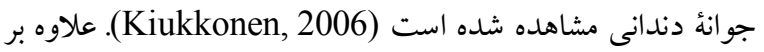
اين مطالعات مختلفى نيز نشان دادهاند كه نانودىاكسيد تيتانيوم سميت سلولى، استرس اكسيداتيو و آيويتوز را از طريق توليد

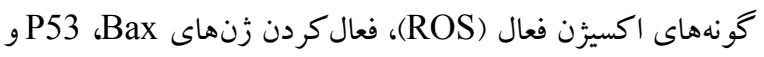

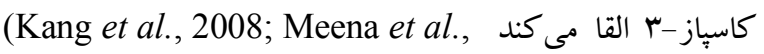
2012,2015) استرس اكسيداتيو توليد شده توسط نانوذرات
دندانى در مراحل ابتدايى رشد و نمو بوده و تنها تغييرات مورفولوزيك در ايىتليوم دهانى داشتهاند. نزديكك به با درصد آنها در مرحلة تيغة دندانى، ·V درصد از آنها در مرحلهُ جوانئ دندانى يا bud و •ادرصد از آنها در مرحلة كلاهكى يا cap قرار داشتهاند. نتايج بهدست آمده از بررسىهاى اين تحقيق نيز نشان داد كه در

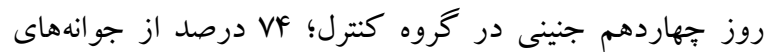

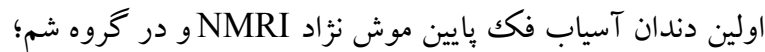

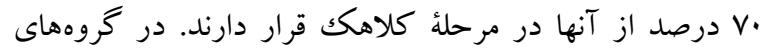
تجربى 1، Y و ץ كاهش جو انهاى دندانى مرحلة cap (به ترتيب

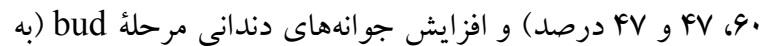

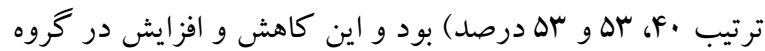
تجربى l و گروههاى تجربى Y و r معنىدار بود. همجينين Kiukkonen و همكاران (2006) در بررسى اثر ديوكسين

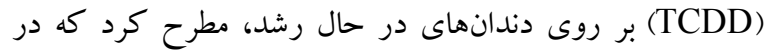

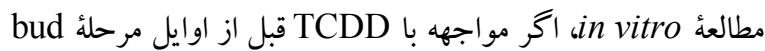
باشد، رشد و نمو دندان متوقف مىشود ولى اخر مواجهه در مر احل بعدى باشد سبب كوجٍك شدن اندازهٔ دندان و دفرمه شدن كاسبّها مىشود. تحقيق روى مرحلهُ رشد و نمو جو انههاى اولين دندان آسياب فك بايين گروههاى تجربى مختلف نشان داد كه

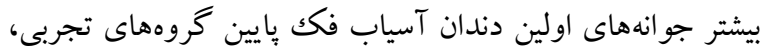

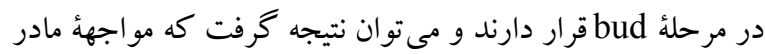
باردار با نانودىاكسيد تيتانيوم در روزهاى دهم تا جهاردهم باردارى سبب توقف و يا به عقب انداختن رشد و نمو جوانه اولين

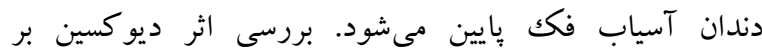
دندانهاى در حال رشد به صورت in vitro نشان داد كه جهار روز كشت جوانهاى دندان آسياب در روز جهاردهم جنينى در

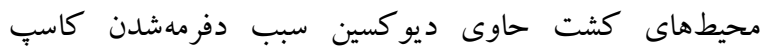

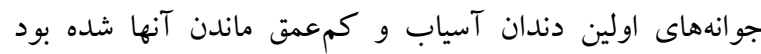
(Kiukkonen, 2006) كاواز دهانى نانودىاكسيد تيتانيوم از روز دهم تا جهاردهم

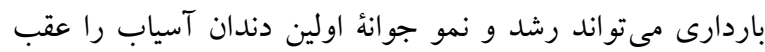

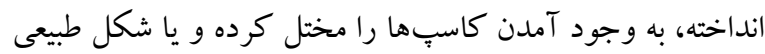
آنها را از بين ببرد. مطالعات متعددى نشان داده است كه سيكار

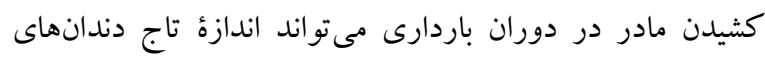




\section{REFERENCES}

Buzea, C., Pacheco, I.I., and Robbie, K. 2007. Nanomaterials and nanoparticles: sources and toxicity. - Biointerphases 2: 17-71.

Chen, T., Yan, J., and Li, Y. 2014. Genotoxicity of titanium dioxide nanoparticles. - J. Food Drug. Anal. 22: 95-104.

Cohn, S.A. 1957. Development of the molar teeth in the albino mouse. - Am. J. Anat. 101: 295-319.

Dechici, P., and Moura, C.C.G. 2005. First molar development in Calomys callosus. - Biosci. J. 21: 159-166.

Dehghani, N., Noori, A., and Modaresi, M. 2014. Investigating the effect of titanium dioxide nanoparticles on the growth and sexual maturation of male rats. - Int. J. Basic Sci. Appl. Res. 3: 772-776.

Duan, Y., Liu, J., Ma, L., Li, N., Liu, H., Wang, J., Zheng, L., Liu, C., Wang, X., Zhao, X., Yan, J., Wang, S., Wang, H., Zhang, X., and Hong, F. 2010. Toxicological characteristics of nanoparticulate anatase titanium dioxide in mice. - Biomaterials 31: 894-899.

Fujishima, A., Rao, T.N., and Tryk, D.A. 2000. Titanium dioxide photocatalysis. - J. Photochem. Photobiol. C Photochem. Rev. 1: 1-21.

Gui, S., Sang, X., Zheng, L., Ze, Y., Zhao, X., Sheng, L., Sun, Q., Cheng, Z., Cheng, J., Hu, R., Wang, L., Hong, F., and Tang, M. 2013. Intragastric exposure to titanium dioxide nanoparticles induced nephrotoxicity in mice, assessed by physiological and gene expression modifications. - Part. Fibre Toxicol. 10: 4. doi: 10.1186/1743-8977-10-4.

Guo, L., Liu, X., Qin, D., Gao, L., Zhang, H., Liu, J., and Cui, Y. 2009. Effects of nanosized titanium dioxide on the reproductive system of male mice. - Zhonghua Nan Ke Xue 15: 517-522.

Hayati Roodbari, N., Parivar, K., Rezaee, S., and Badiee, A. 2014. Comparison of the effects of nano titanium dioxide with $10 \mathrm{~nm}$ diameter on testis and E-pididymis of edult male mice NMRI strain in "in vivo" conditions. - EAB J. 3: 27-38.

Hayati Roodbari, N., Parivar, K., Badiei, A., and Zolfaghari Barogh, S. 2014. Cytotoxic effects of nano-titanium dioxide on forelimb bud development in NMRI mouse embryos in vivo. - ZUMS J. 22: 1124.

Heikkinen, T., Alvesalo, L., and Osborne, R.H. 1994. Intercuspal distances of the first permanent molar with special reference to maternal smoking during pregnancy. - Acta Med. Auxol. 26: 103-114.

Heikkinen, T., Alvesalo, L., Osborne, R.H., Pirttiniemi, P., and Tienari, J. 1992. Maternal smoking and tooth formation in the foetus. I. Tooth crown size in the deciduous dentition. - Early Hum. Dev. 40: 49-59.

Heikkinen, T., Alvesalo, L., Osborne, R.H., and Tienari, J. 1994. Maternal smoking and tooth formation in the foetus. II. Tooth crown size in the permanent dentition. - Early Hum. Dev. 40: 73-86.

Hiatt, J.L., Gartner, L.P., and Provenza, D.V. 1974. Molar development in the mongolian gerbil (meriones unguiculatus). - Am. J. Anat. 141: 1-21.
منى تو اند روى ترميم DNA سلولى و آيويتوز با اثر گذارى بر ساختار بروتئين تأثير گذارد. روى هم رفته، اين دادهها نشان مىدهد كه نانوذرات (Chen et al., است يكك عامل زنوتو كسيك غير مستقيم باشند

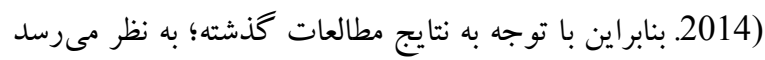
كه يكى از مكانيسمهاى جلو گيرى از رشد و نمو و كاهش اندازهُ دندان، آيويتوز باشد. در مطالعه اثر نانودى اكسيد تيتانيوم روى رشد و نمو دندان، در برخى از جنينهاى گروه تجربى Y كه جوانههاى دندانى آن بيشترين آسيب را نشان داده بودند، عدم اتصال

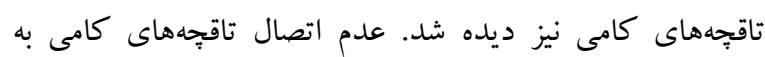
شكاف كام منجر مىشود. مىتوان فرض كرد كه متصل نشدن

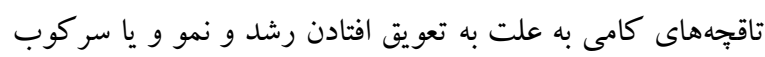
رشد و نمو باشد، كه اين موضوع نيازمند بررسىهاى بيشتر است. نتيجه كيرى يافتهاى تحقيق حاضر نشان داد كه نانودىاكسيد تيتانيوم مىتواند موجب كاهش رشد شود و از ييشرفت رشد و نمو جوانه دندانى جلو گيرى كند. در نهايت بايد كفت با توجه به اين كه رشد و نمو دندان به طور معمول در ارزيابىهاى ايمنى نظارت هماند داروسازى، حشره كشها و ديخر سموم، مطالعه نمىشود؛ بايد به رشد و نمو دندان در مطالعات رشد و نموى توجه بيشترى داشت.

\section{سياسگز ارى}

بدينوسيله از دكتر نسيم حياتى رودبارى كه در تهية نانو ماده استفاده شده در اين تحقيق ما را يارى رساندند تشكر مى گردد.

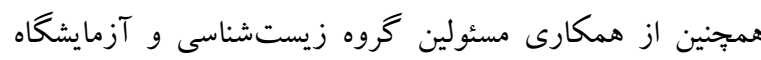
رازى دانشگاه آزاد اسلامى واحد علوم و تحقيقات تهران قدردانى مى شود. 
Löschner, K., Larsen, E.H., Birkedal, R.K., Vibenholt, A., Boisen, A.M.Z., Wallin, H., and Vogel, U. 2010. Effects of prenatal exposure to surface-coated nanosized titanium dioxide (UV-Titan). A study in mice. Part. Fibre Toxicol. 7: 1-15.

Iavicoli, I., Leso, V., Fontana, L., and Bergamaschi, A. 2011. Toxicological effects of titanium dioxide nanoparticles: a review of in vitro mammalian studies. Eur. Rev. Med. Pharmacol. Sci. 15: 481-508.

Jeon, Y.M., Kim, W.J., and Lee, M.Y. 2012. Studies on liver damage induced by nanosized-titanium dioxide in mouse. - J. Environ. Biol. 34: 283-287.

Kang, S.J., Kim, B.M., Lee, Y.J., and Chung, H.W. 2008. Titanium dioxide nanoparticles trigger p53-mediated damage response in peripheral blood lymphocytes. Environ. Mol. Mutagen. 49: 399-405.

Kim, J.Y., Cha, Y.G., Cho, S.W., Kim, E.J., Lee, M.J., Lee, J.M., Cai, J., Ohshima, H., and Jung, H.S. 2006. Inhibition of apoptosis in early tooth development alters tooth shape and size. - J. Dent. Res. 85: 530535.

Kiukkonen, A. 2006. Toxicity of dioxin to developing teeth and salivary glands. - Dep. Oral Pathol. Citeseer, Helsinki.

Lefkowitz, W., Bodecker, C.F., and Mardfin, D.F. 1953. Odontogenesis of the rat molar: prenatal stage. - J. Dent. Res. 32: 749-772.

McCormick, J. 2006. Chemistry of TiO2 Nanoparticles. Ph.D. Thesis, Fac. Univ. Delaware. University of Delaware.

Meena, R., Kumar, S., and Paulraj, R. 2015. Titanium oxide ( $\mathrm{TiO} 2)$ nanoparticles in induction of apoptosis and inflammatory response in brain. - J. Nanoparticle Res. 17: 1-14.

Meena, R., Rani, M., Pal, R., and Rajamani, P. 2012. Nano-TiO2-induced apoptosis by oxidative stressmediated DNA damage and activation of p53 in human embryonic kidney cells. - Appl. Biochem. Biotechnol. 167: 791-808.

Oberdörster, G., Maynard, A., Donaldson, K., Castranova, V., Fitzpatrick, J., Ausman, K., Carter, J., Karn, B., Kreyling, W., Lai, D., Olin, S., Monteiro-Riviere, N., Warheit, D., and Yang, H. 2005. Principles for characterizing the potential human health effects from exposure to nanomaterials: elements of a screening strategy. - Part. Fibre Toxicol. 2: 8. doi.org/10.1186/1743-8977-2-8.

Oberdörster, G., Oberdörster, E., and Oberdörster, J. 2005. Nanotoxicology: an emerging discipline evolving from studies of ultrafine particles. - Environ. Health Perspect. 113: 823-839.

Payne, T.M., Gartner, L.P., Hiatt, J.L., and Provenza, D.V. 1977. Molar odontogenesis in the hairless mouse. - Acta Anat. (Basel). 98: 264-274.

Russo, P.L., and Gartner, L.P. 1987. First molar odontogenesis in the golden Syrian hamster (Cricetus auratus). - Anat. Anz. 164: 275-289.

Salmela, E. 2011. The effects of organic environmental toxicants on hard tissue formation in developing tooth; an in vitro study in mice. - Ph.D thesis, University of Helsinki.
Sayes, C.M., Wahi, R., Kurian, P.A., Liu, Y., West, J.L., Ausman, K.D., Warheit, D.B., and Colvin, V.L. 2006. Correlating nanoscale titania structure with toxicity: a cytotoxicity and inflammatory response study with human dermal fibroblasts and human lung epithelial cells. - Toxicol. Sci. 92: 174-185.

Shi, H., Magaye, R., Castranova, V., and Zhao, J. 2013. Titanium dioxide nanoparticles: a review of current toxicological data. - Part. Fibre Toxicol. 10: 1-33.

Umezawa, M., Tainaka, H., Kawashima, N., Shimizu, M., and Takeda, K. 2012. Effect of fetal exposure to titanium dioxide nanoparticle on brain development \& minus; brain region information. - J. Toxicol. Sci. 37: 1247-1252.

Wang, J., Zhou, G., Chen, C., Yu, H., Wang, T., Ma, Y., Jia, G., Gao, Y., Li, B., and Sun, J. 2007. Acute toxicity and biodistribution of different sized titanium dioxide particles in mice after oral administration. Toxicol. Lett. 168: 176-185.

Xiao, X., Ouyang, K., Liu, R., and Liang, J. 2009. Anatase type titania nanotube arrays direct fabricated by anodization without annealing. - Appl. Surf. Sci. 225: 3659-3663.

Zhao, X., Ze, Y., Gao, G., Sang, X., Li, B., Gui, S., Sheng, L., Sun, Q., Cheng, J., Cheng, Z., Hu, R., Wang, L., and Hong, F. 2013. Nanosized $\mathrm{TiO}(2)$-induced reproductive system dysfunction and its mechanism in female mice. - PLoS One 8: e59378.

$* * * * *$

How to cite this article:

Tabatabaei Nia, S.S., Farhadi, M. and Parivar, K. 2017. Histological investigation of the effects of nano titanium dioxide on the development of the first mandibular molar bud in NMRI mouse strain in vivo. - Nova Biologica Rep. 4: 137-146.

$$
\begin{aligned}
& \text { طباطبائىنيا. س.س.، فرهادى. م. و يريور، ك. وهฬا. بررسى هيستولوزيكى }
\end{aligned}
$$

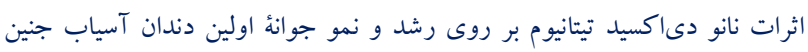

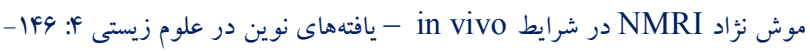

